\title{
Synthesis and characterization of hydrophobic and hydrophilic cellulose derivative by esterification
}

\author{
Taehong Kim***, Sangku Lee**, Byunghee Son**, Hyun-Jjong Paik***, Sanghyeon Yoon**** and \\ Heesoo Lee L***, $^{*}$ \\ *National Core Research Center for hybrid materials solution, Pusan National University, Busan 609-735, Korea \\ **Green material reaserch team Samsung Fine Chemicals CO., LTD., Ulsan 680-090, Korea \\ ***Department of Polymer Science and Engineering, Pusan National University, Busan 609-735, Korea \\ ****School of Materials Science \& Engineering, Pusan National University, Busan 609-735, Korea
}

(Received November 21, 2012)

(Revised November 28, 2012)

(Accepted December 14, 2012)

\begin{abstract}
Acetylated Cellulose Ether (ACE), cellulose-based amphiphilic polymer with hydrophilic and hydrophobic, was synthesized and investigated in terms of its solubility and wettability for organic solvents and water. Acetyl group was substituted to the cellulose ether in a hydrophilic polymer by esterification. As a result of FT-IR, the peak corresponding to the hydroxyl group decreased and carboxyl acid peak increased with increasing reaction time and temperature, which signified the increase in the degree of acetylation of the ACE. There were similar thermal decomposition behaviors before and after esterification reaction until $800^{\circ} \mathrm{C}$ so that the reaction occurred without significant structural changes of cellulose backbones. The solubility parameter of the ACE had a range of 18.5 26.4, and its viscosity and turbidity were controlled according to the solubility parameter of organic solvents. The ACE showed the hydrophilicity because the contact angle of the ACE was higher than the cellulose ether. These results confirmed that the ACE had the hydrophobicity and hydrophilicity due to the ether which was glucosidic bonding between the glucose units and un-reacted hydroxyl functional groups in the ACE.
\end{abstract}

Key words Hydrophobic, Hydrophilic, Acetylated cellulose ether (ACE), Esterification, Solubility

\section{친수성과 소수성을 동시에 가지는 아세틸화 셀룰로스 에테르의 합성 및 특성 평가}

\author{
김태홍***, 이상구**, 손병희 $* *$, 백현종***, 윤상현 ****, 이희수****,† \\ *부산대학교 하이브리드소재 솔루션 국가핵심연구센터, 부산, 609-735 \\ **삼성정밀화학 그린소재연구팀, 울산, 680-090 \\ ****부산대학교 고분자공학과, 부산, 609-735 \\ *****부산대학교 재료공학부, 부산, 609-735
}

(2012년 11월 21일 접수)

(2012년 11월 28일 심사완료)

(2012년 12월 14일 게재확정)

요 약 친수성과 소수성을 동시에 갖는 아세틸화 셀룰로스 에테르(ACE)를 합성하여 유기용매 용해도 및 거동 평가와 물에 대한 젖음성을 평가하였다. 친수성 고분자인 셀룰로스 에테르에 에스테르화 반응을 통해 아세틸기를 치환시켰으며, FT-IR 분석결과 수산화기의 감소와 카르복실산의 증가를 통해 아세틸화 반응을 확인하였다. 열분해 거동 분석결과 $800^{\circ} \mathrm{C}$ 까 지 셀룰로스와 셀룰로스 에테르와 유사한 분해거동을 보여 셀룰로스 주사슬의 구조변화 없이 치환 반응이 일어난 것을 확 인하였다. 18.5 26.4의 solubility parameter의 값을 예상할 수 있는 ACE는 유기용매의 solubility parameter 값에 의해 탁도와 점도가 결정되었다. 합성한 $\mathrm{ACE}$ 의 접촉각은 셀룰로스 에테르 보다 높은 값을 보였으나 시간에 따른 접촉각 변화는 유사한 경향을 보였다. 이는 치환된 아세틸기에 의한 소수성, 무수 글루코스 단위체 내의 반응하지 않고 잔존하는 수산화기에 의 해 친수성을 동시에 가지는 것을 알 수 있었다.

\footnotetext{
Corresponding author

Tel: +82-51-510-2388

Fax: +82-51-512-0528

E-mail: heesoo@pusan.ac.kr
} 


\section{1. 서 론}

셀룰로스 에테르계 유도체인 alkyl hydroxy alkyl cellulose(alkyl=H, - $\mathrm{CH} 3,-\mathrm{CH} 2 \mathrm{CH} 3,-\mathrm{CH} 2 \mathrm{CH}(\mathrm{OH}) \mathrm{CH} 3)$ 는 친환경 소재로 타일 시멘트, 플라스터, 압출, 페인트 등 의 산업분야 및 식품용에 널리 이용되고 있다[1-4]. 이들 셀룰로스 에테르계 유도체는 비수용성 고분자인 셀룰로 스를 수용성 고분자로 변화 시킨 것이 가장 큰 특징이다. 무수 글루코스 단위체들의 glucosidic 결합으로 이루어 진 셀룰로스는 중합도(degree of polymerization)가 수백 에서 수천 정도로 알려져 있고, 분자량은 수만에서 수십 만 정도 이다[5]. 각각의 무수 글루코스 단위체 들은 세 개의 수산화기 $(-\mathrm{OH})$ 를 가지고 있음에도 불구하고 셀룰 로스가 비수용성 고분자인 이유는 각각의 셀룰로스의 글 루코스 단위체의 수산화기간의 수소결합에 의해 결정화 를 이루고 있기 때문이다. 그 결정화도는 40 80\%정도로 알려져 있다 $[6,7]$. 수소 결합을 하고 있는 수산화기를 수산화 나트름 $(\mathrm{NaOH})$ 으로 활성화시킨 후 에테르화 치 환 반응을 시킨 것이 셀룰로스 에테르이며, 대부분의 셀 룰로스 에테르 유도체는 무수 글루코스 단위체에 있는 수산화기와 치환된 알킬기에 의해 수용성 고분자의 성질 을 갖게 된다. 따라서 셀룰로스 에테르는 건축용 혼화제, 페인트 증점제, 식품용 첨가제, 의약용 등 여러 산업에서 사용되며 요구되는 물성에 따라 다양한 치환도와 점도값 을 갖는다.

물질과 물질사이의 계면특성은 산업과 연구 등 여러 분야에서 매우 중요한 성질 중의 하나이며, 실제로도 이 에 관한 연구가 활발히 진행되고 있다 $[8,9]$. 수용성 고 분자인 셀룰로스 에테르는 물을 사용하는 산업에서는 활 용이 가능하나 유기계 산업 용도에서는 적용이 불가능하 다. 특히 높은 분자량의 값을 갖는 셀룰로스는 고강도 수처리 분리막 소재로써 적용이 예상되지만 수용성의 특 성 때문에 적용에 어려움이 있다. 따라서 셀룰로스 에테 르에 소수성의 작용기를 치환시켜 비수용성 고분자로의 적용이 가능하다면 고강도 셀룰로스 수처리 분리막 소재 로의 적용이 가능할 것이다. 현재 수처리 분리막의 가장 대표적인 소재는 $\mathrm{PVDF}$ (polyvinylidene fluoride) 로써 소수성을 가지는 비수용성 고분자이다[10]. 하지만 PVDF 는 소수성의 성질 때문에 내오염성과 수투과성이 떨어지 는 것으로 알려져 있으며 멤브레인 사용 후 폐기시 환경 오염의 문제를 야기시킬 수 있다. 이를 개선하기 위해 친수성을 갖는 작용기를 치환시키는 연구가 진행되어 왔 다. Hashim과 Boributh et al.의 연구에서는[11, 12] 소수 성을 띠는 PVDF에 친수성을 띠는 poly(ethylene glycol) methyl ether methacrylate를 가교시켜 친수성을 갖는 modified PDVF를 합성하였다.

본 연구에서는 친수성 고분자인 소재인 셀룰로스 에테
르에 소수성의 작용기인 아세틸기 $(\mathrm{CH} 3 \mathrm{COO})$ 를 에스테 르화 반응을 통해 치환시켜 소수성과 친수성을 동시에 갖는 양쪽 친매성 고분자인 $\mathrm{ACE}$ (Acetylated Cellulose Ether)를 합성하였다. $\mathrm{ACE}$ 의 접촉각 변화 및 IR spectra 를 이용하여 양쪽 친매성을 확인하였으며, TGA-DSC를 이용한 열적거동과 유기 용매에 따른 용해도, 점도, 탁도 평가를 통해 $\mathrm{ACE}$ 의 유기 용제성을 확인하였다.

\section{2. 실험방법}

\section{1. 합성}

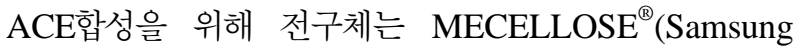
Fine Chemicals Co., Ltd.) PMA-40H(HydroPropylMethyl Cellulose, $\mathrm{DS}=1.80 / \mathrm{MS}=0.25$ )를 사용하였으며, 반응 용매로는 초산(Samsung-BP Chemical, contents $99.0 \%$ or more acetic acid)을 사용하였다. 아세틸화 반응은 무 수초산(Eastman, Anhydrous)을 사용하였고, 반응 촉매 로는 초산소다(DAEJUNG Chemicals and Metals, contents $99.0 \%$ or more sodium acetae)를 사용하였다.

초산 $280 \mathrm{~g}$ (weight ratio 7.0 to Cellulose Ether)과 acetic anhydride $220 \mathrm{~g}$ (weight ratio 5.5 to Cellulose Ether)을 $1 \mathrm{~L}$ 반응기에 넣고 30 분간 $\operatorname{Disc}$ type(DI $=80$ $\mathrm{mm}$ ) 임팰라를 이용하여 교반하였다. 이후 반응기에 열 수를 순환 시키며 반응기를 가열하였으며, $45^{\circ} \mathrm{C}$ 에 초산 소다 $60 \mathrm{~g}$ (weight ratio 1.5 to Cellulose Ether)을 첨가 하여 교반 및 가열하였다. $75^{\circ} \mathrm{C}$ 에서 전구체인 $\mathrm{PMA}-$ $40 \mathrm{H} 40 \mathrm{~g}$ (weight ratio 1.0 to Cellulose Ether)을 첨가 후 $80^{\circ} \mathrm{C}$ 에서 8 시간 동안 유지하였다. 합성 후 증류수 $25 \mathrm{~g}$ 을 반응기에 첨가하여 반응을 종료 시키고 증류수 $225 \mathrm{~g}$ 을 더 투입하여 반응 용액을 희석시켰다. 희석 된 반응 용액을 증류수에 스프레이 방사 시키면 반응물 이 석출되고 여과와 건조 공정을 통해 $\mathrm{ACE}$ 를 합성하 였다.

\section{2. 특성 평가}

아세틸화 반응 확인을 위해 FT-IR spectrometer (EQUINOX55, BRUKER) 측정 및 $\mathrm{ASTM}(\mathrm{D}-871-96)$ 'Standard test methods of Testing Cellulose Acetate Combined Acetyl or acetyl acid contents'로 ACE의 비 누화 반응을 이용한 acetyl값을 정량 분석하였다. 유기용 제 용해성 확인을 위해 대표적인 유기 용제 7종을 선정 하여 상온에서의 용해성을 평가하고, 4 종의 유기 용매를 선정 후 $5 \%$ 용액에서의 점도와 탁도를 평가하였다. 점 도는 $20^{\circ} \mathrm{C}, 5 \%$ 용액에 대해 회전점도계 $(\mathrm{LV}$, brookfield $)$ 
를 이용하여 점도 level에 따라 spindle(no. 61 63)을 선 택하였으며, 탁도는 spectrophotometer(DR/2000, HACH) 를 이용하여 $450 \mathrm{~nm}$ 파장의 빛을 투과시켜 측정하였다. 접촉각 평가를 위해 셀룰로스 에테르는 $5 \%$ 수용액, $\mathrm{ACE}$ 는 $\mathrm{DMF} 5 \%$ 용액을 만든 후 $500 \mu \mathrm{m}$ casting applicator를 사용해 필름을 제조하였다. 각각의 필름을 유리판에 고정 시킨 후 $10 \mathrm{ml}$ 의 증류수로 접촉각을 측 정하였으며(Theta optical tensiometer, KSV instruments), 정확한 측정을 위해 증류수를 필름 위에 떨어뜨린 후 1 분에서 10 분까지 총 5 회 측정하였으며 각각의 측정은 0.2 초 간격으로 10 초 동안 총 50 회 측정 후 평균값을 계산하였다.

\section{3. 결과 및 고찰}

셀룰로스의 무수 글루코스 단위체에 있는 세개의 수산 화기는 활성화 되어 있지 않아 셀룰로스는 비수용성 고 분자이지만 알킬기 등을 치환시킴으로써 수용성 고분자 인 셀룰로스 에테르가 만들어 진다. 이와 같은 원리로 셀 룰로스 에테르의 잔존하는 수산화기 및 hydroxyporpyl기 말단에 있는 수산화기를 아세틸기(-COCH3) 치환시키게 되면 유기용제 용해성 고분자인 $\mathrm{ACE}$ 가 합성될 것으로 판단된다.
Fig. 1은 셀룰로스의 치환 반응에 따른 $\mathrm{ACE}$ 의 합성 모식도를 보여준다. 셀룰로스의 에테르화 반응을 통해 셀룰로스의 수산화기 중 일부를 다른 치환체로 치환함으 로써 수용성 고분자인 셀룰로스 에테르가 얻어지게 되고, 이후 무수초산을 통해 일부 수산화기를 아세틸화 시킴으 로써 $\mathrm{ACE}$ 를 얻게 된다. 이러한 반응의 중량비 및 전구 체의 분석치를 Table 1 에 나타내었다. DS(Methyl) $=1.85$, $\mathrm{MS}$ (Hydroxypropyl $)=0.25$ 인 셀룰로스 에테르 전구체를 사용하여 초산을 반응 용매, 초산소다를 촉매로 하여 무 수초산을 이용하여 아세틸화 반응을 통해 $17.5 \%$ 의 아 세틸화 값을 가지는 $\mathrm{ACE}$ 를 합성하게 되었다.

Fig. 2에서는 (a) 셀룰로스 에테르와 (b) ACE의 FT-IR spectra를 보여준다. (a) 셀룰로스 에테르는 3500 3200 $\left(\mathrm{cm}^{-1}\right)$ 의 영역에서 phenol -OH 에서 해당하는 broad한 peak이 확이 되었으며, 이는 다량의 수산화기가 존재하 는 것을 의미한다. 반면 (b) ACE의 경우 3500 3200 $\left(\mathrm{cm}^{-1}\right)$ 의 peak intensity가 줄어들었으며, $1760 ~ 1690\left(\mathrm{~cm}^{-1}\right)$ 영역의 carboxylic acid $\mathrm{C}=\mathrm{O}$ 에 해당하는 peak intensity 가 급격하게 증가한 것을 확인할 수 있다. 이는 수산화 기가 초산소다에 의해 활성화되고 무수초산과 반응하여 에스테르 반응인 아세틸기의 치환 반응이 일어났기 때문 임을 알 수 있다. Fig. 3에 나타낸 셀룰로스 에테르의 반응 시간과 온도에 따른 아세틸화 정도 변화에서는 반 응 시간이 길어 질수록 $3500 ~ 3200\left(\mathrm{~cm}^{-1}\right)$ 의 peak는 점점

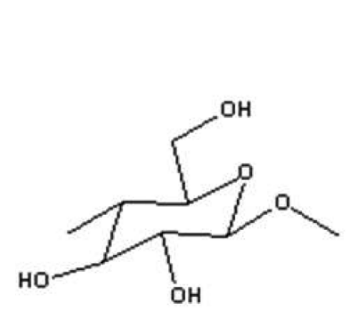

cellulose

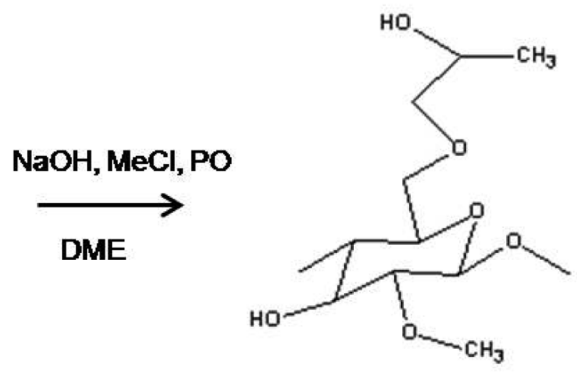

Cellulose ether

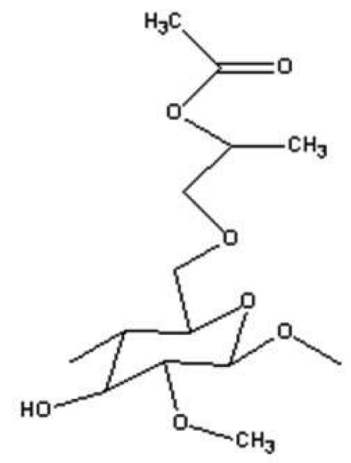

Acetylated cellulose ether

Fig. 1. Schematic diagram for synthesis route of acetylated cellulose ether.

Table 1

Acetylation of MECELLOSE ${ }^{\circledR}$ (cellulose ether) with acetylation agents

\begin{tabular}{|c|c|c|c|c|c|}
\hline & Weight ratio & $\begin{array}{l}\text { DS } \\
\text { (Methyl) }\end{array}$ & $\begin{array}{l}\text { MS } \\
\text { (Hydroxy Propyl) }\end{array}$ & $\begin{array}{l}\text { Viscosity (cps) } \\
(2 \%, 20)\end{array}$ & Acetylation \\
\hline Cellulose ether (MECELLOSE ${ }^{\circledR}$ ) & 1.0 & 1.80 & 0.25 & 3650 & - \\
\hline Acetic acid & 7.0 & - & - & - & - \\
\hline Acetic anhydride & 5.5 & - & - & - & - \\
\hline Sodium acetate & 1.5 & - & - & - & - \\
\hline $\mathrm{ACE}$ & - & - & - & - & 19.2 \\
\hline
\end{tabular}




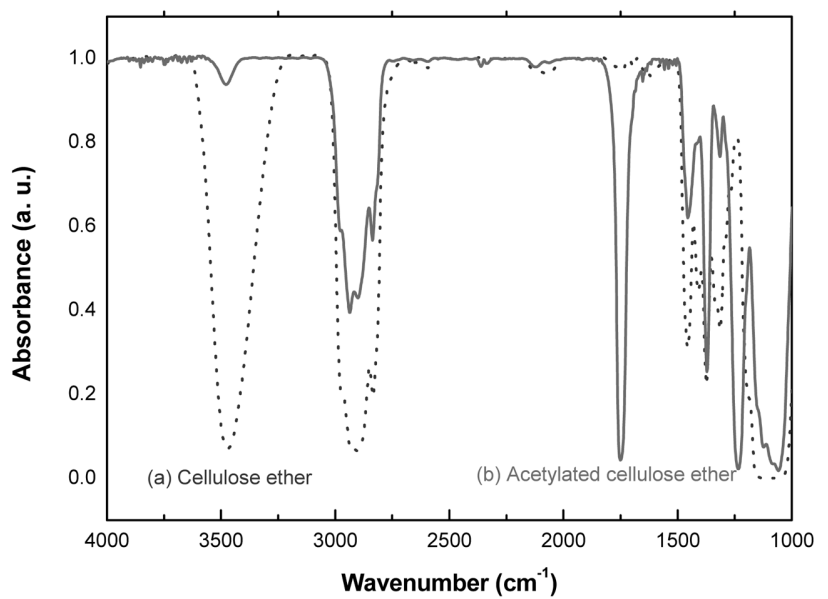

Fig. 2. FT-IR spectra of (a) cellulose ether, (b) acetylated cellulose ether.
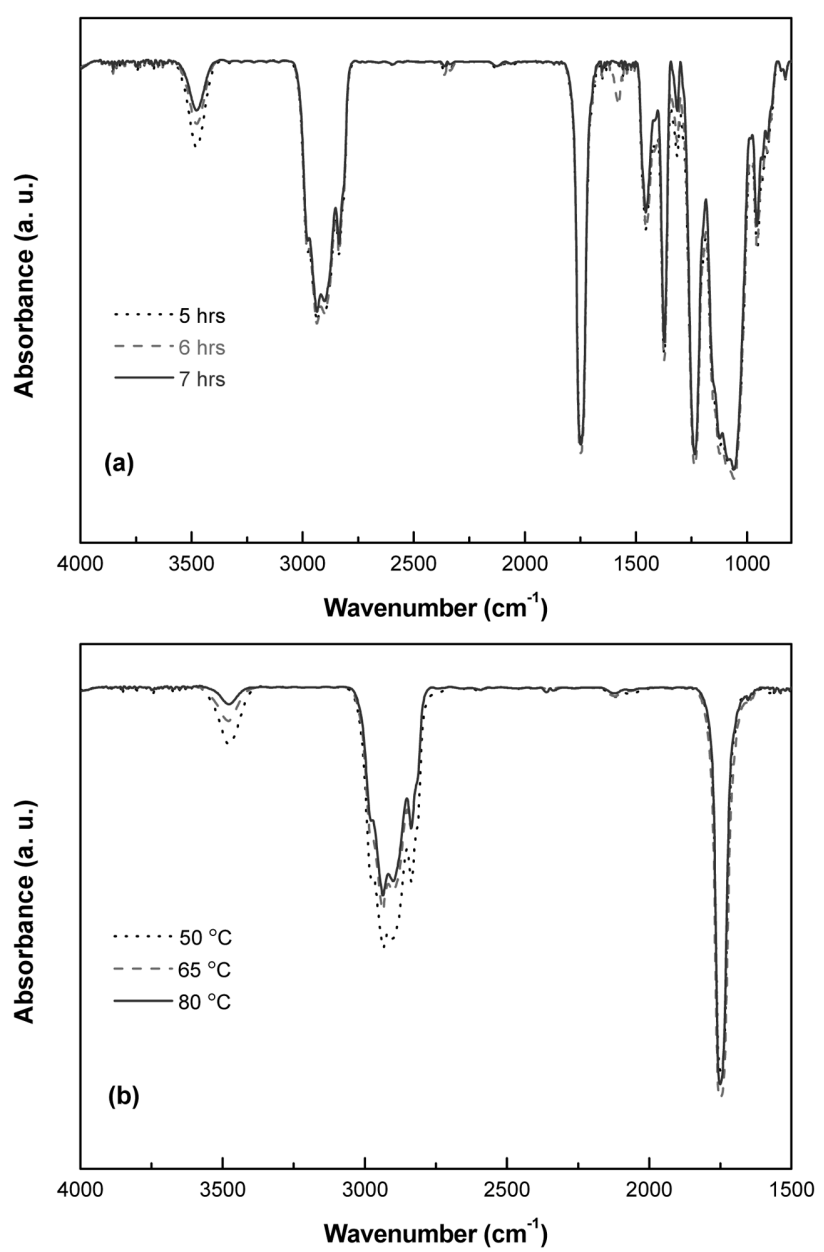

Fig. 3. FT-IR spectra of cellulose ether with different (a) reaction time and (b) reaction temperature.

줄어 들게 되고 $1760 ~ 1790\left(\mathrm{~cm}^{-1}\right)$ 의 intensity값은 점점 증 가함을 알 수 있다. 또한 반응 온도가 증가함에 따라 동 일한 경향을 보였으며, 이를 통해 반응시간 및 온도가 증가할수록 아세틸화 반응이 증가하는 것을 알 수 있다.

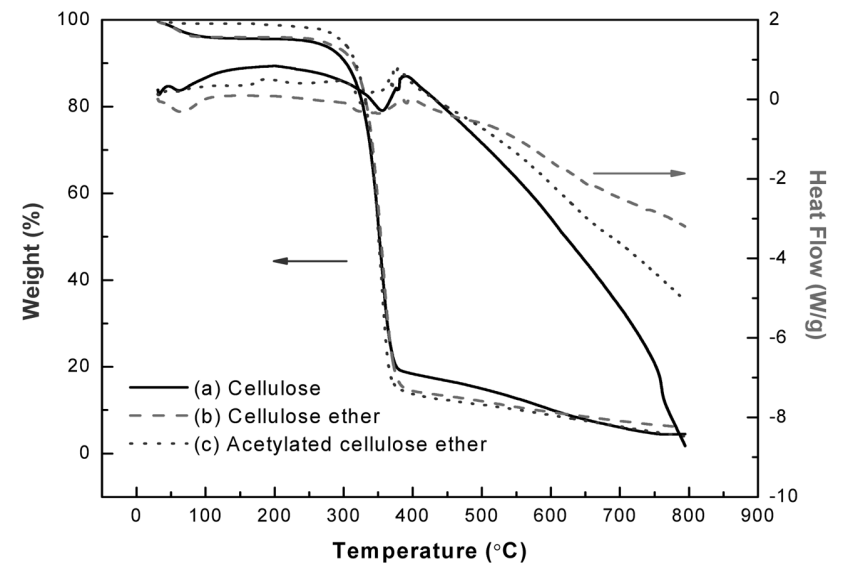

Fig. 4. TGA-DSC curve of (a) cellulose, (b) cellulose ether, and (c) acetylated cellulose ether.

따라서, 반응 시간 및 온도 제어를 통해 수산화기의 조 절이 가능하게 되어 $\mathrm{ACE}$ 의 친수도의 제어가 가능함을 알 수 있다.

Fig. 1의 반응 모식도와 같이 합성한 셀룰로스, 셀룰로 스 에테르, $\mathrm{ACE}$ 의 열분해 거동을 비교하여 Fig. 4에 나 타내었다. 각각의 고분자는 모두 $320^{\circ} \mathrm{C}$ 에서 급격한 중량 감소와 $400^{\circ} \mathrm{C}$ 부근에서의 발열 peak를 보였으며, $360^{\circ} \mathrm{C}$ 이후 서서히 중량감소가 일어나 동일한 열분해 거동을 보이는 것을 알 수 있다. 또한 $600^{\circ} \mathrm{C}$ 이전에 $90 \%$ 이상 중량 감소가 일어났으며, 이는 glucosidic 결합이 열에 의해 분해 되었기 때문임을 알 수 있다. 동일한 열분해 거동을 보인 3 개의 고분자는 셀룰로스 주사슬의 구조에 변화가 없어 친수성의 치환기와 소수성의 치환기가 치환 된 것을 알 수 있다.

$\mathrm{ACE}$ 의 유기용매 용해도에 대한 평가를 위해 대표적 인 유기용매 8종에 대한 용해도를 평가하여 Table 2에 나타내었다. 친수성을 갖는 셀룰로스 에테르는 물에서만 용해되었고 유기용매에는 전혀 용해되지 않았다. 반면 셀룰로스 에테르의 수산화기에 소수성의 치환체를 도입한 $\mathrm{ACE}$ 는 5 종의 유기용매에서 약 $5 \%$ 에서 $11 \%$ 까지 용해 되고, 2 종의 유기용매는 부분적 용해, 그리고 메탄올에서 는 용해되지 않았다. 이를 Hansen solubility parameter와 연관지어 보면 18.5 26.4의 solubility parameter 범위의 값을 가지는 용매에서는 투명하게 용해되고, 그 외에 값 에서는 부분적 용해 또는 용해되지 않는 것을 알 수 있 다. 따라서 합성한 ACE는 18.5 26.4 범위 내의 solubility parameter를 가짐을 예상할 수 있다.

Table 3은 상기 유기용매들 중 대표적인 유기용매 4종 에 대한 $\mathrm{ACE}$ 용액 점도 및 탁도를 보여준다. $\mathrm{ACE}$ 는 유 기용매에 따라 359 899 cps로 다양한 범위의 점도값을 갖게 되는 것을 알 수 있다. 탁도 값이 작을수록 점도는 높아지는 경향을 확인 할 수 있으며, 21.4의 solubility 
Table 2

Solubility of ACE and boiling points of organic solvents

\begin{tabular}{lllll}
\hline Organic solvent & Boiling point $\left({ }^{\circ} \mathrm{C}\right)$ & ${ }^{*}$ Hansen solubility parameter & ACE solubility & Disolution at $25^{\circ} \mathrm{C}$ \\
\hline Acetic acid & $117 \sim 118$ & 21.4 & Clear & $\sim 11 \%$ \\
DMF & $152 \sim 154$ & 24.7 & Clear & $\sim 8 \%$ \\
DMSO & 189 & 26.4 & Clear & $\sim 5 \%$ \\
THF & $65 \sim 67$ & 18.5 & Clear & $\sim 5 \%$ \\
Acetone & 56 & 20 & Clear & $\sim 7 \%$ \\
Toluene & 110 & 18.3 & Partialy & - \\
n-Butyl acetate & 127 & 17.4 & Partialy & - \\
Methanol & 65 & 29.6 & Non-soluble & - \\
\hline
\end{tabular}

*Hansen Parameters for Solvents at $25^{\circ} \mathrm{C}$ (values selected from Hansen's 1971 parameters listed in Handbook of Solubility Parameters, Allan F. M. Barton. Ph.D., CTC Press, 1983, page 153-157).

Table 3

Turbidity and viscosity of ACE solutions

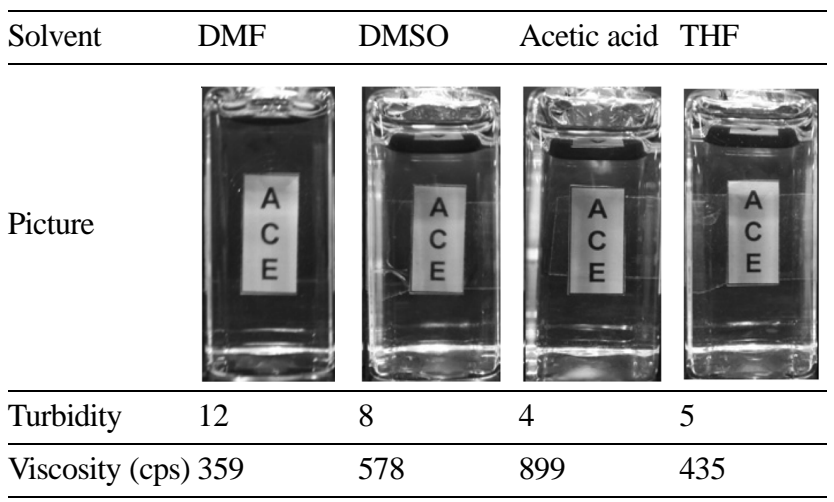

parameter 값을 가지는 초산에서 점도 $899 \mathrm{cps}$, 탁도 4 의 값이 확인 되었다. 또한 24.7의 solubility parameter 값을 가지는 $\mathrm{DMF}$ 에서 점도 359 , 탁도 12 의 값을 보여 용매의 solubility parameter 값에 따라 용해도 및 탁도 에 영향을 미치는 것을 확인 할 수 있다. 이를 통해
$\mathrm{ACE}$ 는 더 이상 물에는 용해되지 않는 소수성을 갖는 셀룰로스 유도체가 되었으며, 또한 친수성을 동시에 갖 는 것을 알 수 있다.

$\mathrm{ACE}$ 의 친수성을 확인하기 위해 접촉각 측정을 통한 젖음성을 비교하여 Table 4에 나타내었다. 셀룰로스 에 테르의 경우 $41.3^{\circ}$ 에서 $18.2^{\circ}$ 로 시간이 지남에 따라 접 촉각이 감소하였고, $\mathrm{ACE}$ 는 $61.7^{\circ}$ 에서 $38.9^{\circ}$ 로 감소하였 다. $\mathrm{ACE}$ 가 셀룰로스 에테르보다 높은 접촉각을 보여 소 수성을 갖는 고분자인 것을 보여준다. 또한 시간이 흐를 수록 친수도에 따라 접촉각이 점점 줄어 들었으며 이를 선형 회귀 분석하여 접촉각 변화 기울기를 확인한 결과, 셀룰로스 에테르가 -5.54, $\mathrm{ACE}$ 가 -5.52으로 유사한 값 을 보여 $\mathrm{ACE}$ 의 친수성의 성질을 함께 갖는 것을 알 수 있다. 따라서 수용성 고분자인 셀룰로스 에테르에 잔존 하는 수산화기의 아세틸화 반응으로 얻은 $\mathrm{ACE}$ 는 반응 하지 않고 남은 수산화기에 의해 친수성을 가지면서 반 응한 아세틸기에 의해 소수성의 성질을 갖는 것을 알 수 있다.

Table 4

Contact angle of cellulose ether and acetylated cellulose ether

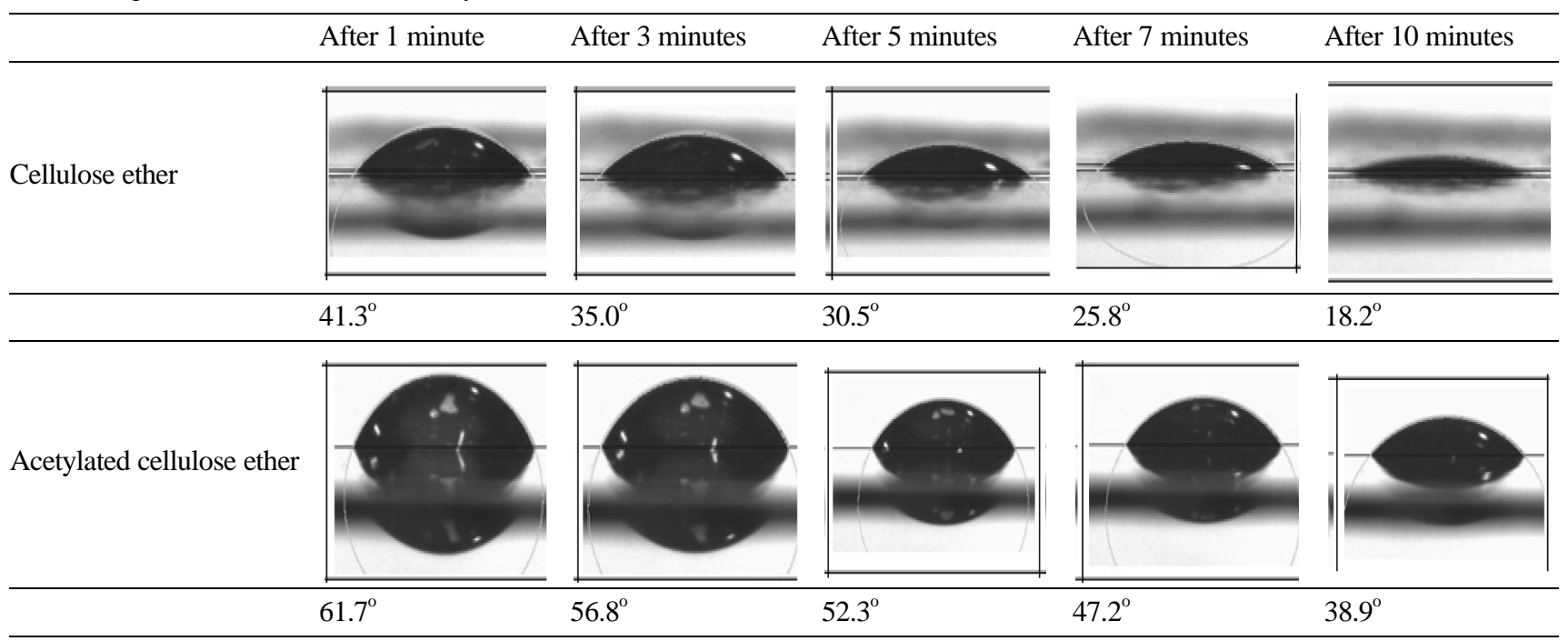




\section{4. 결 론}

셀룰로스 에테르에 무수초산을 이용하여 에스테르화 반 응인 아세틸화 치환 반응으로 양쪽 친매성 셀룰로스 유도 체인 $\mathrm{ACE}$ (Acetylated Cellulose Ether)를 합성하였다. FT-IR spectrum의 수산화기 peak 감소와 carbonyl $(\mathrm{C}=\mathrm{O})$ peak 증가를 통해 아세틸화 반응을 확인 하였으며 반응 온도와 반응 시간이 증가할수록 아세틸화 정도(degree of substitution)가 증가하였다. $\mathrm{ACE}$ 와 셀룰로스, 셀룰로 스 에테르간의 유사한 열분해 거동을 확인함으로써 아세 틸화 반응을 통한 셀룰로스 주사슬의 구조 변화 없이 소 수성의 치환기와 친수성의 치환기가 함께 치환된 양쪽 친매성 셀룰로스 유도체를 합성 할 수 있었다. $\mathrm{ACE}$ 는 상온에서 $\mathrm{DMF}, \mathrm{DMAC}$ 등 유기 용제에서 각각 $8 \%$, $5 \%$ 용해되어 유기 용제 용해성을 확인하였으며, 셀룰로 스 에테르에 비해 접촉각이 평균 $20 \%$ 높아 보다 소수 성의 성질을 보였다. 또한 시간이 지남에 따라 접촉각이 감소하여 친수성의 성질을 동시에 가짐을 확인하였다. 이는 셀룰로스 에테르의 수산화기의 부분적인 아세틸화 반응에 의한 것임을 알 수 있었다.

\section{감사의 글}

본 연구는 한국연구재단을 통해 교육과학기술부의 선 도연구센터육성사업 학제간융합분야(NCRC)(2011-0006257)의 연구비 지원으로 수행되었으며 이에 감사 드립니다.

\section{참 고 문 헌}

[1] J. Pourchez, A. Govin, P. Grosseau, R. Guyonnet, B. Guilhot and B. Ruot, "Alkaline stability of cellulose ethers and impact of their degradation products on cement hydration", Cem. Concr. Res. 36 (2006) 1252.

[2] K.L. Krumel and T.A. Lindsay, "Nonionic cellulose ethers", Food Science and Technology 30 (1976) 36.

[ 3 ] J. Pourchez, A. Peschard, P. Grosseau, R. Guyonnet, B. Guilhot and F. Vallee, "HPMC and HEMC influence on cement hydration", Cem. Concr. Res. 36 (2006) 288.

[4] S.G. Croll and R.L. Kleinlein, "Influence of cellulose ethers on coatings performance", in Water-Soluble Polymers, J. E. Glass, Editor, American Chemical Society 213 (1986) 333.

[5] M.L.R. Medina and V. Kumar, "Comparative evaluation of powder and tableting properties of low and high degree of polymerization cellulose I and cellulose II excipients", Int. J. Pharm. 337 (2007) 202.

[6] L. Segal, J.J. Creely, A.E. Martin Jr. and C.M. Conrad, "An empirical method for estimating the degree of crystallinity of native cellulose using the X-ray diffractometer", Text. Res. J. 29 (1959) 786.

[7] S.K. Park, J.O. Baker, M.E. Himmel, P.A. Parilla and D.K. Johnson, "Research Cellulose crystallinity index: measurement techniques and their impact on interpreting cellulase performance", Biotechnol. Biofuels 3 (2010) 1 .

[ 8 ] D.H. Kim and B.S. Min, "Melt-solid interface and segregation in horizontal Bridgman growth using 2- and 3dimensional pseudo-steady-state model", J. of Korean Association of Crystal Growth 5 (1995) 306.

[9] C.S. Lim and Hubertus Nickel, "Interface chemistry of SiC/Co reaction", J. of Korean Association of Crystal Growth 5 (1995) 109.

[10] N. Yamato, K. Kimura, T. Miyoshi and Y. Watanabe, "Difference in membrane fouling in membrane bioreactors (MBRs) caused by membrane polymer materials", J. Membr. Sci. 280 (2006) 911.

[11] S. Boributh, A. Chanachai and R. Jiraratananon, "Modification of PVDF membrane by chitosan solution for reducing protein fouling”, J. Membr. Sci. 342 (2009) 97.

[12] N.A. Hashim, F. Liu and K. Li, "A simplified method for preparation of hydrophilic PVDF membranes from an amphiphilic graft copolymer", J. Membr. Sci. 345 (2009) 134. 